\section{Applying Calcium Chloride Postharvest to Improve Highbush Blueberry Firmness}

\author{
Eric J. Hanson, Jane L. Beggs, and Randolph M. Beaudry \\ Department of Horticulture, Michigan State University, East Lansing, \\ MI 48824-1325
}

\section{Additional index words. Vaccinium corymbosum}

\begin{abstract}
Immature and marketable highbush blueberries often are separated by buoyancy in water tanks. Calcium chloride was added to the water to improve berry firmness or integrity. Berries were immersed in $0 \%$ to $4 \% \mathrm{CaCl}_{2}$ and held at $2 \mathrm{C}$ for several days. Vertical compression of a column of berries decreased linearly with increased $\mathrm{CaCl}_{2}$ concentration, a result indicating that $\mathrm{CaCl}_{2}$ increased the ability of the berries to resist physical damage. Immersion duration $(0.5,2$, or 4 minutes) did not affect results. However, rinsing berries in water immediately after immersing them in $\mathrm{CaCl}_{2}$ negated the effect. Taste panelists associated an objectionable, salty taste with berries immersed in $2 \%$ and $4 \% \mathrm{CaCl}_{2}$, but not for those immersed in $1 \% \mathrm{CaCl}_{2}$.
\end{abstract}

A high frequency of crushed or broken berries reduces the grade [U.S. Dept. of Agriculture (USDA)] of frozen blueberries. Berries may be damaged during harvesting and sorting on the farm, in transport to a freezing facility, and during freezing. This is particularly true for overripe berries or when freezing is delayed. Improving the firmness or integrity of berries before freezing may reduce the number of crushed or broken berries, thus avoiding grade reductions.

Tissue $\mathrm{Ca}$ concentrations influence fruit texture, firmness, and ripening rate. Apples

Received for publication 7 Jan. 1993. Accepted for publication 28 May 1993. We acknowledge the Michigan Agricultural Experiment Station for supporting this research. The cost of publishing this paper was defrayed in part by the payment of page charges. Under postal regulations, this paper therefore must be hereby marked advertisement solely to indicate this fact.
(Malus domestica Borkh.) often are treated commercially pre- and postharvest with $\mathrm{Ca}$ solutions (Ferguson and Watkins, 1989). Preharvest $\mathrm{CaCl}_{2}$ sprays increase the firmness of strawberries (Fragaria $\times$ ananassa Duch.) (Cheour et al., 1990; Eaves and Leefe, 1962) and raspberries (Rubus idaeus L.) (Eaves et al., 1972). Calcium may maintain fruit firmness by delaying postharvest ripening (Cheour et al., 1990). The relationship between tissue $\mathrm{Ca}$ concentration and blueberry firmness is not known. Reported $\mathrm{Ca}$ concentrations in blueberries range from $0.039 \%$ to $0.32 \%$ of dry matter (Ballinger et al., 1958; Bishop et al., 1971).

Blueberries destined for processing often are immersed in water tanks to separate the less-dense green berries from the mature berries (Wolfe et al., 1975). In Michigan, water sorting is done on the farm, and sometime may elapse before berries are frozen. Quality can decline during this time if berries are overripe or mishandled in transit to the freezer; therefore, berries may be treated with $\mathrm{CaCl}_{2}$ in the sorting tank. These studies examined the effects of postharvest $\mathrm{CaCl}_{2}$ immersion on firmness and quality of highbush blueberries.

Four studies were conducted during 1991 and 1992. In each study, $\approx 1 \mathrm{~kg}$ of mature berries was placed in plastic mesh bags and immersed in treatment solutions. Berries were held for various periods to allow them to soften and to simulate commercial delayedfreezing conditions. Berry firmness was assessed indirectly by evaluating the ability of the berries to resist physical damage. Rigid polyvinylchloride pipe $(50 \mathrm{~cm}$ long, $4 \mathrm{~cm}$ i.d., with an end cap) was filled with berries. The tube was shaken gently to settle the berries, then held vertically and dropped four times on a hard surface from $10 \mathrm{~cm}$ high. The column height of berries was measured before and after dropping, and the vertical compression was calculated.

In Study 1, 'Bluecrop' blueberries were immersed in $0 \%, 0.25 \%, 1.0 \%$, or $4.0 \% \mathrm{CaCl}_{2}$ for $0.5,2$, or $8 \mathrm{~min}$. Treated berries, still in

Table 1. Effect of $\mathrm{CaCl}_{2}$ concentration (C) and immersion duration (D) on compression of 'Bluecrop' blueberries determined after berries had been held for 5 days at $2 \mathrm{C}$ plus 3 days at $18 \mathrm{C}$ (Study 1).

\begin{tabular}{cc}
\hline Variable & $\begin{array}{c}\text { Compression } \\
(\mathrm{cm})\end{array}$ \\
\hline $\mathrm{C}(\%)$ & 9.6 \\
0 & 9.5 \\
0.25 & 8.7 \\
1.0 & 8.2 \\
4.0 & \\
$\mathrm{D}(\mathrm{min})$ & 9.1 \\
0.5 & 9.0 \\
2.0 & 8.8 \\
4.0 & \\
Significance & $\mathrm{L*}$ \\
$\mathrm{C}$ & $\mathrm{NS}$ \\
$\mathrm{D}$ & $\mathrm{NS}$ \\
$\mathrm{C} \times \mathrm{D}$ & \\
\hline
\end{tabular}

ss, "Nonsignificant or significant at $P \leq 0.01$ by $\mathrm{F}$ test; $\mathbf{L}=$ linear. 
mesh bags, were held for 5 days at $2 \mathrm{C}$ plus 3 days at $18 \mathrm{C}$ and tested for compression. A completely randomized, $4 \times 3$ factorial design was used, with five replications.

In Study 2, 'Jersey 'blueberries were immersed in $0 \%, 1 \%, 2 \%, 3 \%$, or $4 \% \mathrm{CaCl}_{2}$ for 2 min. Treated berries were held for 3 days at $2 \mathrm{C}$ plus 3 days at $18 \mathrm{C}$ before evaluating compression. After compression, berries were removed from the tube and frozen at -20C. Several weeks later, berries were sorted while frozen, and nondamaged, moderately damaged (dented or deformed), arid severely damaged (crushed or broken) berries were counted. A completely randomized design was used, with six replications.

Study 3 determined whether rinsing berries after immersion in $\mathrm{CaCl}_{2}$ affected their response. 'Jersey' blueberries were immersed in $4 \% \mathrm{CaCl}_{2}$ for $2 \mathrm{~min}$. Samples were washed immediately by briefly immersing the bags twice in water, held at $2 \mathrm{C}$ for 2 or 4 days and washed by the same procedure, or not washed. All berries were held for 4 days at $2 \mathrm{C}$ plus 3 days at $18 \mathrm{C}$ before being tested for compression. A completely randomized design was used, with six replications.

In Study 4, taste tests were conducted to determine if $\mathrm{CaCl}_{2}$ immersion resulted in detectable changes in the taste of fresh or frozen and thawed berries that were not rinsed after treatment. 'Bluecrop' blueberries were used for the fresh tests, and 'Jersey' blueberries for the frozen and thawed tests. Berries were dipped in $0 \%, 1 \%, 2 \%$, or $4 \% \mathrm{CaCl}_{2}$ for $2 \mathrm{~min}$. Four panelists first tasted berries treated with $0 \%$ and $8 \% \mathrm{CaCl}_{2}$ to familiarize themselves with the taste of $\mathrm{CaCl}_{2}$ Nonsalty fruit received a rating of 0 , and berries equivalent to those treated with $8 \% \mathrm{CaCl}_{2}$ received a rating of 10 . Panelists then rated unknown samples on the same scale of $0=$ no salty taste, $10=$ strong salty taste. Berries that were frozen after immersion and thawed several weeks later were given the same test. Four replications were evaluated by each panelist.

Analysis of variance and $\mathrm{F}$ tests were used to test for significant treatment effects. The variance was partitioned into the linear component in Studies 1 and 2, and least significant difference values were used to separate means in Studies 3 and 4.

Increasing $\mathrm{CaCl}_{2}$ concentrations in Studies 1 and 2 resulted in linear reductions in compression levels (Tables 1 and 2), a result indicating that berries immersed in $\mathrm{CaCl}_{2}$ resisted physical damage to a greater extent than those not immersed. Immersion in $\mathrm{CaCl}_{2}$ for $0.5,2$, or 8 min each seemed equally effective (Table 1). Increasing $\mathrm{CaCl}_{2}$ concentrations decreased the percentage of severely damaged fruit and increased the percentage of nondamaged fruit (Table 2).

Although the compression test resulted in excessive damage (29\% to $39 \%$ crushed or broken berries) by commercial standards, it seemed to be useful in measuring berry sus-
Table 2. Effect of $\mathrm{CaCl}_{2}$ concentration on compression and degree of damage to blueberries (after the compression test) determined after berries had been held for 3 days at $2 \mathrm{C}$ plus 3 days at $18 \mathrm{C}$ (Study 2).

\begin{tabular}{|c|c|c|c|c|}
\hline \multirow{2}{*}{$\begin{array}{l}\mathrm{CaCl}_{2} \\
\text { concn }(\%)\end{array}$} & \multirow{2}{*}{$\begin{array}{c}\text { Compression } \\
(\mathrm{cm})\end{array}$} & \multicolumn{3}{|c|}{$\begin{array}{c}\text { Berry damage } \\
(\%)^{\mathrm{z}}\end{array}$} \\
\hline & & $\mathbf{N}$ & $\mathrm{M}$ & $S$ \\
\hline 0 & 10.1 & 19 & 42 & 40 \\
\hline 1 & 9.6 & 21 & 44 & 35 \\
\hline 2 & 9.1 & 21 & 46 & 32 \\
\hline 3 & 9.3 & 23 & 48 & 30 \\
\hline 4 & 8.7 & 29 & 42 & 29 \\
\hline Significance & $\mathbf{L}^{* *}$ & $\mathrm{~L}^{* *}$ & $\mathbf{L}^{\mathrm{Ns}}$ & $\mathrm{L}^{* *}$ \\
\hline
\end{tabular}

${ }^{\mathrm{x}} \mathrm{N}=$ none (no visible damage), $\mathbf{M}=$ moderate (dented, deformed), S = severe (crushed, broken). Ns,"**Nonsignificant or significant at $P \leq 0.01$, respectively; $\mathrm{L}=$ linear.

Table 3. Effect of rinsing 'Jersey' blueberries after immersing them in $4 \% \mathrm{CaCl}_{2}$ for $2 \mathrm{~min}$ on their compression after holding them for 4 days at $2 \mathrm{C}$ plus 3 days at $18 \mathrm{C}$ (Study 3 ).

\begin{tabular}{lc}
\hline Rinsing & $\begin{array}{c}\text { Compression } \\
(\mathrm{cm})\end{array}$ \\
\hline None & $9.2 \mathrm{a}^{\mathrm{z}}$ \\
Immediate & $10.3 \mathrm{~b}$ \\
After 2 days & $8.7 \mathrm{a}$ \\
After 4 days & $8.8 \mathrm{a}$ \\
\hline
\end{tabular}

${ }^{x}$ Means separated by $L S D, P \leq 0.05$.

ceptibility to physical damage. The percentage of severely damaged fruit and level of compression were strongly correlated $(r=$ $0.80, P \leq 0.01)$. USDA Grade A blueberries must have $<6 \%$ crushed or broken berries, but dented and misshaped berries do not reduce the grade.

The compression of berries washed immediately after $\mathrm{CaCl}_{2}$ immersion was greater than that of berries washed 2 or 4 days after immersion or not washed at all (Table 3). Residual $\mathrm{CaCl}_{2}$ remained on the surface of berries during the 6 to 8 days between immersion and compression tests. This residue seems to be necessary for the increased resistance to compression, an observation suggesting that Ca maybe absorbed by berries or affect their integrity gradually. Blueberries have a waxy surface that may limit their permeability to $\mathrm{CaCl}_{2}$. The water spray that rinses berries as they exit some commercial water tanks may remove residual $\mathrm{CaCl}_{2}$ from berries and, thus, reduce the benefit of $\mathrm{CaCl}_{2}$ immersion. Neither immersion nor rinsing led to fruit cracking.

Panelists found a salty taste to be associated with increasing $\mathrm{CaCl}_{2}$ concentrations when tasting fresh berries on the same day they were treated (Table 4). A salty taste also was detected in berries that were frozen and thawed; it was present in berries treated with $2 \%$ or $4 \%$ $\mathrm{CaCl}_{2}$ but not in berries treated with $1 \% \mathrm{CaCl}_{2}$ (Table 4). This result suggests that $1 \% \mathrm{CaCl}_{2}$ can be used without adversely affecting the flavor of frozen berries.

How $\mathrm{CaCl}_{2}$ immersion affected fruit $\mathrm{Ca}$
Table 4. Effect of $\mathrm{CaCl}_{2}$ concentration on the taste rating of fresh 'Bluecrop' and frozen and thawed 'Jersey' blueberries (Study 4).

\begin{tabular}{lcc}
\hline & \multicolumn{2}{c}{ Taste rating } \\
\cline { 2 - 3 } $\mathrm{CaCl}_{2}$ & Fresh & $\begin{array}{c}\text { Frozen and } \\
\text { thawed }\end{array}$ \\
\hline 0 & $2.4 \mathrm{a}^{\mathrm{y}}$ & $3.9 \mathrm{ab}$ \\
1 & $5.0 \mathrm{~b}$ & $2.9 \mathrm{a}$ \\
2 & $6.1 \mathrm{~b}$ & $4.8 \mathrm{~b}$ \\
4 & $8.5 \mathrm{c}$ & $6.5 \mathrm{c}$ \\
\hline
\end{tabular}

${ }^{\mathrm{z}}$ Rating on a scale of 0 (no salty taste) to 10 (strong salty taste).

${ }^{y}$ Means separated in columns by LSD, $P \leq 0.05$.

concentrations is not known, since no fruit were analyzed. The effect of immersion on berry integrity did not seem to be associated with a $\mathrm{Ca}$ deficiency, since berries for these studies were obtained from several commercial plantings.

These studies indicated that adding $\mathrm{CaCl}_{2}$ to water sorting tanks increases the ability of blueberries to resist physical damage, as long as they are not rinsed as they exit the tanks. However, treatments cannot be recommended commercially, since $\mathrm{CaCl}_{2}$ concentrations that provided the greatest benefit ( $2 \%$ to $4 \%$ ) also resulted in an objectionable taste in frozen blueberries. Perhaps applying $\mathrm{CaCl}_{2}$ preharvest would provide similar benefits without adversely affecting taste. Also, a periodic difficulty with density separation in water tanks is that some ripe berries float and are removed with the immature berries. Adding $\mathrm{CaCl}_{2}$ will increase the density of the separation medium and may increase the proportion of mature berries removed during the separation process.

\section{Literature Cited}

Ballinger, W.E., A.L. Kenworthy, H.K. Bell, E.J. Benne, and S.T. Ball. 1958. Relationship between nutrient element content of blueberry foliage and fruit. Michigan State Univ. Quarterly Bul. 40:906-911.

Bishop, R.F., L.R. Townsend, and D.L. Craig. 1971. Effect of source and rate of $\mathrm{N}$ and $\mathrm{Mg}$ on nutrient levels in highbush blueberry leaves and fruit. HortScience 6:37-38.

Cheour, F., C. Willemot, J. Arul, Y. Desjardins, J. Makhlouf, P.M. Charest, and A. Gosselin. 1990. Foliar application of calcium chloride delays postharvest ripening of strawberry. J. Amer. Soc. Hort. Sci. 115:789-792.

Eaves, C.A. and J.S. Leefe. 1962. Note on the influence of foliar sprays of calcium on the firmness of strawberries. Can. J. Plant Sci. 42:746-747.

Eaves, C.A., C.L. Lockhart, R. Stark, and D.L. Craig. 1972. Influence of preharvest sprays of calcium salts and wax on fruit quality of red raspberry. J. Amer. Soc. Hort. Sci. 97:706-707.

Ferguson, I.B. and C.B. Watkins. 1989. Bitter pit in apple fruit. Hort. Rev. 11:289-355.

Wolfe, R.R., H.S. Jalli, M.J. Ceponis, and R.A. Cappellini. 1975. Evaluation of density separation to remove immature fruit from mechanically harvested blueberries. Trans. Amer. Soc. Agr. Eng. 17:760-764. 